\title{
Antimicrobial and Cytotoxic Activities of the Crude Extracts and Isolated Compounds of Xylocarpus mollucensis
}

\author{
Md. Enamul Haque, Md. Nahidul Islam, Md. Hafizur Rahman \\ and Akim Uddin Mohamad
}

Department of Biochemistry and Molecular Biology, University of Dhaka, Dhaka-1000, Bangladesh

\begin{abstract}
The fractionated crude extracts and three isolated pure compounds XM-1, XM-2 and XM-3 from stem bark of Xylocarpus mollucensis were screened for their antibacterial and antifungal activities and cytotoxicity against brine shrimp nauplii. Petroleum ether, ethyl acetate (EtOAc) and methanol $(\mathrm{MeOH})$ extracts and the compounds isolated from EtOAc fractions were studied for their antimicrobial activities. Cytotoxic activities were conducted only with EtOAc extract and its selected fractions. The EtOAc extract showed promising antimicrobial activities against all the gram positive and gram negative bacteria whereas petroleum ether extract showed moderate activities and the $\mathrm{MeOH}$ extract did not show any antimicrobial activities. The isolated pure compounds XM-1, XM-2 and XM-3, whose structures were not elucidated, exhibited activities against most of the bacterial strains. The cytotoxicity towards brine shrimp nauplii of the crude EtOAC extract and its selected fractions were studied. The $\mathrm{LC}_{50}$ values of the EtoAc extract was $12.6 \mu \mathrm{g} / \mathrm{ml}$ and for the fractions 2, 5, 8 and 13 were 17.78, 13.34, 14.13 and $15.85 \mu \mathrm{g} / \mathrm{ml}$, respectively.
\end{abstract}

Key words: Antimicrobial, Cytotoxic, Xylocarpus, Meliaceae.

\section{INTRODUCTION}

The genus Xylocarpus mollucensis (Meliaceae) comprises 16 species of trees, which are distributed in the Indian subcontinent, Malaysia and Australia. ${ }^{1}$ Limonoids have been isolated from the species Xylocarpus mollucensis, Amoora grandifoloia, A. rohituka and A. wallichii., ${ }^{2,3}$ Phytochemical investigation of the different species of Meliaceae resulted in the isolation of essential ester, terpenoids and steroids etc. ${ }^{4}$ Xylocarpus mollucensis is a big tree that is widely distributed in the forest of Sundarban at Khulna district of Bangladesh. Xylocarpus mollucensis is said to cure dysentery, diarrhoea and abdominal troubles (Banglapedia).

Correspondence to: Md. Enamul Haque Tel.: 96619200-73/7949; Fax: 88-02-8615583

Dhaka Univ. J. Pharm. Sci. 6(2): 109-112, 2007 (December)
So far no detail phytochemical and biological studies have been carried out on this plant. In the present study, antimicrobial activities of the crude extracts and isolated compounds from EtOAc extract and cytotoxic activities of the EtOAc and selected fractions of the stem bark of Xylocarpus mollucensis have been discussed.

\section{MATERIALS AND METHODS}

The stem bark of Xylocarpus mollucensis was collected from the forest of Sundarban at Khulna district of Bangladesh. The sun-dried stem bark was ground mechanically and extracted in a soxhlet apparatus successively with petroleum ether, ethyl acetate and methanol. The extracts were then concentrated in vacuo using a Buchii rotavapor. The 
EtOAc extract was then fractionated by vacuum liquid chromatography (VLC) over silica gel. Pure compounds were then isolated and purified from different fractions using different types of chromatographic techniques.

The in vitro antibacterial and antifungal activities of the crude extracts as well as the isolated pure compounds were determined by disc diffusion technique. ${ }^{5}$ Sixteen bacterial strains, which included five gram positive and eleven gram negative organisms and eight fungi were collected from the Department of Microbology and Institute of Nutrition and Food Sciences, University of Dhaka. Nutrient agar media was used for the culture of bacteria and potato dextrose agar media was used for the culture of fungi. In brief, a measured amount of the test samples was dissolved in definite volumes of $\mathrm{CHCl}_{3}$ to give solutions of known concentration $(\mu \mathrm{g} / \mathrm{ml})$. The sterile Matricel (BBL, cocksville USA) filter paper discs were impregnated with known amounts of the test substances and dried. Standard ampicillin disc $(10 \mu \mathrm{g} / \mathrm{ml})$ and disc on which $\mathrm{CHCl}_{3}$ was adsorbed and dried (blank disc) were used as positive and negativre controls, respectively.

The disc was then placed in petridises $(120 \mathrm{~mm}$ in diameter) containing Mueller- Hinton agar media seeded with the test organisms using sterile cotton swabs. The plates were then incubated at $37^{\circ} \mathrm{C}$ for 24 hours. The antimicrobial activities were measured from zone of inhibition expressed in $\mathrm{mm}$. All experiments were carried out in triplicate and the mean of the readings were recorded. ${ }^{6}$ The cytotoxic activities were performed by Brine shrimp lethality test. $^{7}$

\section{RESULTS AND DISCUSSION}

The antimicrobial and antifungal activities of the petroleum ether, EtOAc and methanol extracts of Xylocarpus mollucensis were determined against sixteen bacterial strains and eight fungi. The results were compared with those produced by the standard antibiotic, ampicillin trihydrate BP $(10 \mu \mathrm{g} / \mathrm{ml})$. The results of the sensitivity are summarized in Table 1 . All strains showed sensitivity toward ethyl acetate

Table 1. Antibacterial activities of different extracts and compounds of Xylocarpus mollucensis

\begin{tabular}{|c|c|c|c|c|c|c|c|}
\hline \multirow{2}{*}{\multicolumn{2}{|c|}{ Bacteria }} & \multicolumn{6}{|c|}{ Zone of inhibition $(\mathrm{mm} \pm \mathrm{SD})$} \\
\hline & & \multirow[t]{2}{*}{$\begin{array}{l}\text { Pet. Ether extract } \\
(3 \mathrm{mg} / \text { disc })\end{array}$} & \multirow[t]{2}{*}{$\begin{array}{l}\text { EtOAc extract } \\
\text { (3 mg/disc) }\end{array}$} & \multirow[t]{2}{*}{ 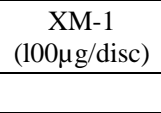 } & \multirow[t]{2}{*}{$\begin{array}{c}\mathrm{XM}-2 \\
(100 \mu \mathrm{g} / \mathrm{disc})\end{array}$} & \multirow[t]{2}{*}{ 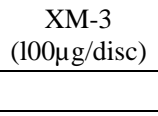 } & \multirow[t]{2}{*}{$\begin{array}{l}\text { Ampicillin } \\
(100 \mu \mathrm{g} / \mathrm{disc})\end{array}$} \\
\hline Gr: & n positive & & & & & & \\
\hline 1 & Bacillus subtilis & - & $14 \pm 0.5$ & $12 \pm 1$ & - & $10 \pm 0.5$ & $22 \pm 0.2$ \\
\hline 2 & B. megaterium & $14 \pm 0.8$ & $16 \pm 0.5$ & $14 \pm 0.2$ & $12 \pm 0.4$ & - & $20 \pm 0.6$ \\
\hline 3 & B. cereus & $12 \pm 0.2$ & $12 \pm 0.8$ & - & $10 \pm 0.3$ & & \\
\hline 4 & Staphylococcus aureus & $12 \pm 0.5$ & $10 \pm 0.4$ & - & - & $12 \pm 0.6$ & $20 \pm 0.3$ \\
\hline 5 & Sarcina lutea & - & $10 \pm 0.5$ & $11 \pm 0.8$ & - & - & $19 \pm 0.2$ \\
\hline \multicolumn{8}{|c|}{ Gram negative } \\
\hline 1 & Shigella sonii & $14 \pm 0.4$ & $18 \pm 0.3$ & $13 \pm 0.5$ & $12 \pm 0.5$ & $14 \pm 0.6$ & $20 \pm 0.2$ \\
\hline 2 & Shigella boydii & $16 \pm 0.2$ & $17 \pm 0.5$ & $12 \pm 0.8$ & - & $14 \pm 0.7$ & $18 \pm 0.3$ \\
\hline 3 & Shigella dysenteriae-type I & $12 \pm 0.3$ & $12 \pm 0.2$ & - & $12 \pm 0.5$ & - & $22 \pm 0.6$ \\
\hline 4 & Shigella dysenteriae-type 2 & - & $14 \pm 0.5$ & - & - & $10 \pm 0.4$ & $18 \pm 0.3$ \\
\hline 5 & Escherichia coli & - & $14 \pm 0.2$ & - & - & $10 \pm 0.5$ & $20 \pm 0.6$ \\
\hline 6 & Pseudomonas aeruginosa & $16 \pm 0.4$ & $18 \pm 0.8$ & $14 \pm 0.7$ & $12 \pm 0.4$ & $14 \pm 0.6$ & $22 \pm 0.2$ \\
\hline 7 & Salmonella typhi & $15 \pm 0.5$ & $14 \pm 0.2$ & $12 \pm 0.3$ & $16 \pm 0.5$ & $16 \pm 0.8$ & $20 \pm 0.5$ \\
\hline 8 & Salmonella paratyphi.A & - & $10 \pm 0.5$ & - & - & - & $16 \pm 0.2$ \\
\hline 9 & Salmonella paratyphi B & $16 \pm 0.5$ & $16 \pm 0.5$ & $10 \pm 0.2$ & $14 \pm 0.6$ & $12 \pm 0.5$ & $19 \pm 0.3$ \\
\hline 10 & Vibrio cholerae & $18 \pm 0.2$ & $16 \pm 0.5$ & $16 \pm 0.4$ & $14 \pm 0.6$ & $16 \pm 0.2$ & $22 \pm 0.5$ \\
\hline 11 & V. mimicus & $14 \pm 0.5$ & $9 \pm 0.8$ & $12 \pm 0.6$ & - & $12 \pm 0.4$ & $20 \pm 0.6$ \\
\hline
\end{tabular}

" - " = Indicates no zone of inhibition. 
extract. Among the Gram-negative bacteria Shigella sonii, Shigella boydii, Pseudomonas aeruginosa and Salmonella paratyphi B and Vibrio cholerae showed promising sensitivity $(16-18 \mathrm{~mm})$ to ethyl acetate extract. B. megaterium is the Gram positive bacteria which showed promising sensitivity toward EtOAc extract. Other Gram positive and Gram-negative organism showed mild sensitivity. The petroleum ether extract demonstrated promising sensitivity against Shigella boydii, Pseudomonas aeruginosa,
Salmonella paratyphi B and Vibrio cholereae; Mild activity against $B$. megaterium, B. cereus, Staphylococcus aureus, Shigella sonii, Shigella dysenteriae-type I, Salmonella typhi and V. mimicus; and no activity was observed against the other bacteria. Mild sensitivity was showed by $B$. megaterium, B. cereus and Staphylococcus aureus against petroleum ether extract. The methanol extract did not show any sensitivity (data not shown).

Table 2. Antifungal activities of the crude extracts and isolated compounds of Xylocarpus mollucensis

\begin{tabular}{|c|c|c|c|c|c|c|c|}
\hline \multirow{2}{*}{\multicolumn{2}{|c|}{ Name of Fungi }} & \multicolumn{6}{|c|}{ Zone of inhibition (mm \pm SD) after 48 hr incubation } \\
\hline & & \multirow{2}{*}{$\begin{array}{l}\text { Pet. Ether extract } \\
\text { (3 mg/l disc) } \\
-\end{array}$} & \multirow{2}{*}{$\begin{array}{l}\text { EtOAc extract } \\
\text { (3 mg/l disc) }\end{array}$} & \multirow{2}{*}{$\begin{array}{c}\begin{array}{c}\mathrm{XM}-1 \\
(100 \mu \mathrm{g} / \mathrm{disc})\end{array} \\
14 \pm 0.2\end{array}$} & \multirow{2}{*}{$\begin{array}{c}\begin{array}{c}\mathrm{XM}-2 \\
(100 \mu \mathrm{g} / \mathrm{disc})\end{array} \\
12 \pm 0.8\end{array}$} & \multirow{2}{*}{$\begin{array}{c}\begin{array}{c}\mathrm{XM}-3 \\
(100 \mu \mathrm{g} / \mathrm{disc})\end{array} \\
13 \pm 0.5\end{array}$} & \multirow{2}{*}{$\begin{array}{c}\begin{array}{c}\text { Ampicillin } \\
(100 \mu g / d i s c)\end{array} \\
22 \pm 0.4\end{array}$} \\
\hline 1 & Aspergilus niger & & & & & & \\
\hline 2 & A. fumigatus & - & $16 \pm 0.2$ & $12 \pm 0.5$ & - & $12 \pm 0.3$ & $20 \pm 0.5$ \\
\hline 3 & Candida albicans & - & - & - & - & - & $18 \pm 0.6$ \\
\hline 4 & C. krusei & - & - & - & - & - & $20 \pm 0.2$ \\
\hline 5 & Candida oryzae & - & $12 \pm 0.5$ & $12 \pm 0.8$ & $9 \pm 0.8$ & - & $22 \pm 0.4$ \\
\hline 6 & Saccharromyces cerevisiae & - & $14 \pm 0.6$ & $10 \pm 0.2$ & $10 \pm 0.6$ & - & $22 \pm 0.5$ \\
\hline 7 & Rhizopus oryzae & - & $12 \pm 0.4$ & $10 \pm 0.6$ & - & $10 \pm 0.5$ & $22 \pm 0.8$ \\
\hline 8 & Trichoderma sp. & - & $15 \pm 0.5$ & $12 \pm 0.6$ & $12 \pm 0.8$ & - & $20 \pm 0.2$ \\
\hline
\end{tabular}

“- " = Indicates no Zone of inhibition.

Table 3. Results of Brine shrimp lethality test of crude extract and selected fractions of Xylocarpus mollucensis.

\begin{tabular}{|c|c|c|c|c|c|c|c|c|c|}
\hline Test samples & \multicolumn{2}{|c|}{$\begin{array}{c}\text { Group conc. } \\
(\mu \mathrm{g} / \mathrm{ml})\end{array}$} & $\begin{array}{l}\text { Brine shrimp } \\
\text { in each vial }\end{array}$ & \multicolumn{2}{|c|}{$\begin{array}{l}\text { Death in } \\
\text { each vial }\end{array}$} & $\begin{array}{c}\text { Average } \\
\text { death }\end{array}$ & $\begin{array}{c}\% \\
\text { mortality }\end{array}$ & $\begin{array}{l}\text { Log } \\
\text { conc. }\end{array}$ & $\begin{array}{c}\mathrm{LC}_{50} \\
(\mu \mathrm{g} / \mathrm{ml})\end{array}$ \\
\hline \multirow{5}{*}{ Crude } & A & 25 & 15 & 12 & 8 & 10 & 67 & 1.4 & \multirow{5}{*}{12.6} \\
\hline & B & 50 & 15 & 14 & 10 & 12 & 80 & 1.7 & \\
\hline & $\mathrm{C}$ & 100 & 15 & 12 & 15 & 13.5 & 90 & 2.0 & \\
\hline & $\mathrm{D}$ & 200 & 15 & 14 & 15 & 14.5 & 97 & 2.3 & \\
\hline & $\mathrm{E}$ & 400 & 15 & 16 & 14 & 15 & 100 & 2.6 & \\
\hline \multirow{5}{*}{ F- 2} & A & 25 & 15 & 9 & 8 & 8.5 & 57 & 1.4 & \multirow{5}{*}{17.78} \\
\hline & B & 50 & 15 & 10 & 10 & 10 & 67 & 1.7 & \\
\hline & $\mathrm{C}$ & 100 & 15 & 12 & 11 & 11.5 & 77 & 2.0 & \\
\hline & $\mathrm{D}$ & 200 & 15 & 13 & 16 & 14.5 & 97 & 2.3 & \\
\hline & $\mathrm{E}$ & 400 & 15 & 16 & 14 & 15 & 100 & 2.6 & \\
\hline \multirow{5}{*}{$F-5$} & A & 25 & 15 & 10 & 11 & 10.5 & 70 & 1.4 & \multirow{5}{*}{13.34} \\
\hline & B & 50 & 15 & 11 & 14 & 12.5 & 83 & 1.7 & \\
\hline & $\mathrm{C}$ & 100 & 15 & 12 & 15 & 13.5 & 90 & 2.0 & \\
\hline & $\mathrm{D}$ & 200 & 15 & 16 & 13 & 14.5 & 97 & 2.3 & \\
\hline & $\mathrm{E}$ & 400 & 15 & 15 & 15 & 15 & 100 & 2.6 & \\
\hline \multirow{5}{*}{$F-8$} & A & 25 & 15 & 11 & 10 & 10.5 & 70 & 1.4 & \multirow{5}{*}{14.13} \\
\hline & B & 50 & 15 & 13 & 11 & 12 & 80 & 1.7 & \\
\hline & $\mathrm{C}$ & 100 & 15 & 12 & 14 & 13 & 87 & 2.0 & \\
\hline & $\mathrm{D}$ & 200 & 15 & 15 & 12 & 13.5 & 90 & 2.3 & \\
\hline & $\mathrm{E}$ & 400 & 15 & 14 & 16 & 15 & 100 & 2.6 & \\
\hline \multirow{5}{*}{$F-13$} & A & 25 & 15 & 9 & 10 & 9.5 & 63 & 1.4 & \multirow{5}{*}{15.85} \\
\hline & B & 50 & 15 & 12 & 9 & 10.5 & 70 & 1.7 & \\
\hline & $\mathrm{C}$ & 100 & 15 & 15 & 12 & 13.5 & 90 & 2.0 & \\
\hline & $\mathrm{D}$ & 200 & 15 & 14 & 15 & 14.5 & 97 & 2.3 & \\
\hline & $\mathrm{E}$ & 400 & 15 & 14 & 16 & 15 & 100 & 2.6 & \\
\hline
\end{tabular}

Where, $\mathrm{F}=$ Fraction. 
It was found that most of the bacterial strains exhibited moderate sensitivity (Table 1 ) against pure compounds XM-1, XM-2 and XM-3 except Salmonella paratyphi-A, Shigella dysenteriae-type 2, Staphylococcus aureus and Sarcina lutea. The ethyl acetate extract showed the prominent zone of inhibition against the fungus, Aspergilus niger and $A$. fumigatus. The petroleum ether extract did not show any antifungal activity. The isolated compounds XM1, XM-2 and XM-3 for antifungal investigations showed moderate zone of inhibitions against Aspergilus niger; small zone of inhibition against $A$. fumigatus, Candida oryzae, Saccharomyces cerevisiae, Rhizopus oryzae and Trichoderma sp.; no zone of inhibition was observed against Candida albicans and C. krusei (Table 2).

It was found from the result of the brine shrimp lethality test in Table 3 that the crude EtOAc extract and the selected fractions of it exhibited toxicity towards brine shrimp. The crude extract was more potent than the selected fractions. Due to insufficiency of samples, the other fractions have not been included in this bioassay. Test samples showed different mortality rate at different concentrations. The mortality rate of brine shrimp was found to be increased with the increase of concentration of each sample. The percent of mortality of the brine shrimp nauplii was calculated for every concentration of each sample. A plot of log concentration of the sample versus percent of mortality showed an approximate linear correlation between them. The $\mathrm{LC}_{50}$ value of the crude ethyl acetate was $12.6 \mu \mathrm{g} / \mathrm{ml}$ and for the fractions 2, 5, 8 and 13 were 17.78, 13.34, 14.13 and $15.85 \mu \mathrm{g} / \mathrm{ml}$ respectively. This plant can be used as a good source of antimicrobial compounds for the treatment of different diseases.

\section{REFERENCES}

1. Hooker, J.D. 1875. Flora of British India. 1, p. 559. Reeve and Co., London.

2. Bandaranayahi, W.M. 1998. Traditional and Medical used mangroves. Mangroves and salt marshes. 2, 133-148.

3. King, T.J. and Taylor, D.A.H. 1983. Limonordy from Meliaceae. Phytochemistrery. 22, 307-390.

4. Nishizawa, M., Inone, A., Hayashi, Y., Sastrapradja, S., Kosla, S. and Iwashita, T. 1984. Terpenoids \& sterirds from different species of Meliaceae. J. org. chem. 49, 3660-64.

5. Bauer, A.W., Kirby, W.M.M., Sherris, J.C. and Turck, M. 1966. Antibiotic susceptibility testing by standardized single disc method. Am. J. Clin. Pathol. 44, 493-496.

6. Jones, N.R., Barry, L.A. Gavan, L.T. and Washington, J.A. 1985. Manual of clinical Microbiology. 4th Edn., p. 972. American Soc. Microbiol. 1913 st. N.W. Washington., DC.

7. Mclaughlin, J.L. and Anderson, J.E. 1990. Bench top bioassays for the discovery of bioactive compounds in higher plants. Brenesa. 29, 443. 